\author{
LIDIA KALISZCZAK \\ Uniwersytet Rzeszowski, Polska - University of Rzeszow, Poland \\ KatarzYNA SierAdZKa \\ Uniwersytet Technologiczno-Humanistyczny im. Kazimierza Pułaskiego w Radomiu, Polska - Kazimierz Pulaski \\ University of Technology and Humanities in Radom, Poland
}

\title{
Kształtowanie postaw przedsiębiorczych studentów wobec współczesnych wyzwań rozwojowych
}

\section{Shaping Entrepreneurial Attitudes of Students towards Contemporary Development Challenges}

\begin{abstract}
Streszczenie: $\mathrm{W}$ artykule podjęto próbę argumentacji tezy, że kształtowanie postaw przedsiębiorczych staje się współcześnie imperatywem wobec zmian zachodzących w otoczeniu, a przedsiębiorczość jest $\mathrm{w}$ dużej mierze postawą aprobowaną przez młode pokolenie, które założenie własnej firmy traktuje jak potencjalną opcję kariery zawodowej. Celem była identyfikacja postaw przedsiębiorczych studentów w kontekście ich znaczenia wobec współczesnych wyzwań rozwojowych. Omówiono rolę edukacji dla właściwego rozumienia istoty i uwarunkowań przedsiębiorczości oraz przejawiania przedsiębiorczych postaw i zachowań dla potrzeb rozwoju nowoczesnej gospodarki i wzrostu dobrobytu społeczeństwa. Na podstawie własnych badań empirycznych przeprowadzono analizę i ocenę przedsiębiorczej postawy studentów, identyfikowanej poprzez cechy osobowościowe, uznawane wartości oraz skłonność do aktywności na rynku pracy przez wybór zawodu przedsiębiorcy jako ścieżki kariery zawodowej. Motywy i przejawy tych zachowań analizowano $\mathrm{z}$ wybranymi czynnikami społecznymi, takimi jak miejsce zamieszkania czy tradycje rodzinne, a także według kategorii płci oraz wybranego profilu kształcenia. Wyniki badań dowodzą, że przedsiębiorczość wśród studentów jest w dużej mierze aprobowaną postawą, ale bycie przedsiębiorcą pozostaje w sferze intencji.
\end{abstract}

\begin{abstract}
The study argues that shaping entrepreneurial attitudes is becoming an imperative today in the face of changes taking place in the environment, and that entrepreneurship among the young generation is a largely approved attitude and starting up your own company is seen as a potential career option. The aim of the research is to identify entrepreneurial attitudes of students in the context of their importance in the face of contemporary development challenges. The role of education was discussed for a proper understanding of the essence and conditions of entrepreneurship, as well as manifesting entrepreneurial attitudes and behavior for the purposes of developing a modern economy and increasing the well-being of the society. Based on own empirical research, an analysis and assessment of the entrepreneurial attitude of students were made. The attitude was determined using personality traits, recognized values and a tendency to be active on the labour market by choosing the profession of entrepreneur as a career path. The motives and manifestations of these behaviours were analysed with selected social factors, such as place of residence, or family traditions, as well as by gender and selected education profile. Research re-
\end{abstract}


sults prove that entrepreneurship among students is largely an approved attitude, however, when comes to career options it remains in the sphere of intentions.

Słowa kluczowe: postawa przedsiębiorcza; przedsiębiorczość; wyzwania rozwojowe

Keywords: development challenges; entrepreneurial attitude; entrepreneurship

Otrzymano: 18 listopada 2019

Received: 18 November 2019

Zaakceptowano: 30 sierpnia 2020

Accepted: 30 August 2020

\section{Sugerowana cytacja/Suggested citation:}

Kaliszczak, L., Sieradzka, K. (2020). Kształtowanie postaw przedsiębiorczych studentów wobec współczesnych wyzwań rozwojowych. Przedsiębiorczość - Edukacja [Entrepreneurship-Education], 16(2), 99-112. doi: 10.24917/20833296.162.8

\section{Wstęp}

Powszechnie uznaje się, że rozwój przedsiębiorczości jest podstawowym czynnikiem wzrostu gospodarczego i dobrobytu społeczeństwa. Już J. Schumpeter wykazał, iż za podstawowy czynnik rozwoju kapitalizmu należy uznać zyski wynikające z kreatywności i innowacyjności przedsiębiorców (Foster, Kaplan, 2003: 287). Aktualność poglądów J. Schumpetera, a także stanowisko P.F. Druckera, wskazującego na konieczność kształtowania się społeczeństwa przedsiębiorczego (Drucker, 1992), uzasadniają potrzebę kształtowania postaw przedsiębiorczych młodego pokolenia. Właściwa edukacja ekonomiczna generuje bowiem potencjał kapitału ludzkiego zdolnego do działań innowacyjnych, implikujących rozwój społeczno-gospodarczy, zwiększenie wydajności, doskonalenie produktów oraz budowę konkurencyjnej gospodarki. Jednym z ważniejszych efektów edukacji jest także zwiększenie poziomu intencji przedsiębiorczych młodego pokolenia, rozumianych jako chęć założenia i prowadzenia własnego biznesu (Rachwał, Wach, 2016). Przedsiębiorca to zawód stwarzający wiele możliwości, zarówno samorozwoju, jak i podnoszenia statutu materialnego, cieszący się również coraz większym prestiżem w społeczeństwie (GEM Polska, 2017: 5, 9).

\section{Cel i metoda badań}

Powyższe przesłanki stanowią określone wymagania dla procesu edukacji - chodzi o przekazywanie młodemu pokoleniu kluczowych wartości i ekonomicznej wiedzy, aby kształtować u młodych ludzi postawy przedsiębiorcze i zachowania w szerszym kontekście współczesnych wyzwań cywilizacyjnych oraz gospodarczych. Odpowiedzi na pytania o to, jaki zakres powinna obejmować oraz w jakim kierunku powinna ewoluować przedsiębiorcza edukacja, należy poszukiwać w teorii klasyków przedsiębiorczości oraz w posiadanych przez młode pokolenie kompetencjach przedsiębiorczych, zarówno w kwestii uznawanych wartości, jak i podejmowanych aktywności. Stąd celem badań empirycznych autorek niniejszego artykułu stała się ocena postaw przedsiębiorczych studentów oraz wybranych czynników determinujących te postawy. Autorki podjęły próbę argumentacji tezy, że kształtowanie postaw przedsiębiorczych staje się współcześnie imperatywem wobec zmian zachodzących w otoczeniu, a założenie własnej firmy przez osobny z młodego 
pokolenia, legitymującego się wyższym wykształceniem, jest w dużej mierze aprobowaną postawą i potencjalną opcją kariery zawodowej.

Dla potrzeb realizacji przyjętego celu pracy oraz argumentacji sformułowanej tezy zaproponowano zadania badawcze, które obejmują:

- przedstawienie współczesnych wyzwań rozwojowych i wykazanie ich wpływu na wzrost znaczenia paradygmatu przedsiębiorczości w objaśnianiu procesów rozwoju społeczno-gospodarczego,

- uzasadnienie potrzeby edukacji w zakresie kształtowania postaw przedsiębiorczych,

- analizę i ocenę postaw przedsiębiorczych studentów wybranych kierunków Uniwersytetu Rzeszowskiego oraz czynników wpływających na ich przejawianie.

Niniejsza praca stanowi teoretyczno-empiryczną refleksję w przedmiotowej problematyce, opartą na literaturze oraz badaniach własnych. Podjęto empiryczną weryfikację przedsiębiorczej postawy studentów, identyfikowanej przez uznawane wartości, cechy osobowościowe oraz skłonność do aktywności na rynku pracy przez wybór zawodu przedsiębiorcy jako ścieżki kariery zawodowej (intencje przedsiębiorcze). Przedmiotem badań było także poszukiwanie związku pomiędzy skłonnością do zakładania własnej firmy a oceną wybranych cech, które odzwierciedlają potencjał przedsiębiorczy ankietowanych. Analizowano następujące cechy wyróżniające postawę przedsiębiorczą studentów: kreatywność, proaktywność, wychodzenie z inicjatywą działań, potrzeba osiągnięć, upór i determinacja, zdolności przywódcze, myślenie strategiczne, wizja, odwaga i podejmowanie ryzyka, wiara we własne możliwości, pracowitość, umiejętności organizacyjne, elastyczność w działaniu. Motywy i przejawy zachowań przedsiębiorczych analizowano z wybranymi czynnikami społecznymi (miejsce zamieszkania, tradycje rodzinne), a także według kategorii płci oraz profilu kształcenia.

Materiał do badań stanowiły dane uzyskane w toku wywiadu $\mathrm{z}$ kwestionariuszem ankiety od osób studiujących na ostatnich latach studiów I i II stopnia Uniwersytetu Rzeszowskiego. Badania o charakterze sondażowym zostały przeprowadzone wśród 136 osób studiujących kierunki zaliczone do trzech grup: ekonomicznych, technicznych i humanistycznych. Po weryfikacji poprawności wypełnienia ankiet do analizy przyjęto 104 kwestionariusze.

Wartością poznawczą opracowania jest regionalny charakter badań, odnoszący się do województwa podkarpackiego.

\section{Współczesne wyzwania rozwojowe a paradygmat przedsiębiorczości}

Współcześnie warunki rozwoju kształtowane są przez następujące współzależne trendy: 1) ewolucja gospodarki industrialnej w kierunku gospodarki opartej na wiedzy (GOW) i tzw. inteligentnej gospodarki ${ }^{1}$. Informacja i wiedza oraz umiejętności ich wykorzystania przesądzają o roli kapitału ludzkiego jako zasobu o charakterze strategicznym (Kaliszczak, Sieradzka, 2018: 3); 2) wzrost złożoności, zmienności i nieprzewidywalności otoczenia oraz znaczna dynamika tempa zmian; 3) zwiększenie konkurencji w warunkach globalizacji rynków światowych oraz presja często radykalnej zmiany jako warunku wyróżnienia się na rynku, osiągnięcia i/lub utrzymania przewagi konkurencyjnej. W obliczu złożonej i szybko zmieniającej się rzeczywistości do wyjaśniania współcześnie zachodzących zjawisk w większym stopniu przystaje paradygmat przedsiębiorczości (Kaliszczak, 2011), bowiem

${ }^{1}$ W świetle Strategii Europa 2020, zatwierdzonej przez Radę Europejską 17 czerwca 2010 r. 
założenia paradygmatu tradycyjnej ekonomii mają ograniczone horyzonty. W miejsce technokratycznego determinizmu proponuje się paradygmat podmiotowej, aktywnej roli człowieka (przedsiębiorcy), zaangażowanego w proces konkurencji przez kreatywność i pomysłowość, działającego w warunkach niepewności. Paradygmat przedsiębiorczości służy tym samym identyfikacji cech wyróżniających postawę przedsiębiorczą oraz wyjaśnieniu przedsiębiorczych zachowań (Wennekers, Thurik, 1999; za: Dominiak, 2005: 79).

W toku edukacji zasadne jest odwołanie się do idei klasyków, które zasadniczo wpłynęły na kształtowanie się pojęcia przedsiębiorczości. Wymienia się trzy główne szkoły myślenia ekonomicznego, którymi są: szkoła oparta na koncepcji innowacji i „twórczej destrukcji” J. Schumpetera, szkoła ukształtowana według poglądów I. Kirznera - umiejętność dostrzegania szans i okazji pojawiających się na rynku oraz szkoła związana z koncepcją F. Knighta - skłonność do podejmowania ryzyka w warunkach niepewności. W pojmowaniu przedsiębiorczości wielu autorów odwołuje się także do klasycznego ujęcia H.H. Stevensona i J.C. Jarillo-Mossiego, wskazujących, że jest to proces tworzenia wartości przez stworzenie unikalnej kombinacji zasobów, aby wykorzystać pojawiające się szanse (Stevenson, Jarillo-Mossi, 1990; za Kraśnicka i in., 2014: 317). Istotę przedsiębiorczości trafnie oddaje także stanowisko J.A. Timmonsa i H.H. Stevensona (1990: 5), podkreślające, że jest to proces tworzenia lub rozpoznawania szans oraz wykorzystywania ich bez względu na posiadane aktualnie zasoby.

\section{Kształtowanie postaw przedsiębiorczych - wyzwania dla edukacji}

Analiza stanowisk klasyków pozwala skonstatować, że kategoria przedsiębiorczości to nie tylko kategoria, w której identyfikujemy skwantyfikowany cel ekonomiczny, ale przede wszystkim kategoria konstytuująca przedsiębiorczą postawę i zachowanie, wyrażane przez myślenie twórcze. Istotne jest zatem kształtowanie poczucia podmiotowości, odwagi w podejmowaniu decyzji i otwartości na zmiany. To podejście ma szczególe znaczenie w rozbudzaniu intencji przedsiębiorczych studentów. Badania w tym zakresie podejmowane przez takich badaczy, jak A. Wąsowska (2016), K. Wach, L. Wojciechowski (2016), A. Żur (2014) dowodzą wpływu różnych czynników na przedsiębiorczą aktywność studentów. Rolą edukacji powinno być uświadomienie możliwości i korzyści z wyboru różnych dróg kariery oraz dostarczenie zasobu wiedzy i umiejętności w zakresie bycia przedsiębiorcą. Dane statystyczne zaprezentowane w tabeli 1 dowodzą, że dyplom wyższej uczelni nie gwarantuje zatrudnienia. Przy malejącej stopie bezrobocia udział w społeczeństwie osób z wyższym wykształceniem pozostających bez pracy wykazywał tendencje wzrostowe (tabela 1).

Tabela 1. Zmiany liczby i udziału osób bezrobotnych z wyższym wykształceniem w ogóle bezrobotnych w Polsce w wybranych latach

\begin{tabular}{|c|c|c|c|}
\hline \multirow{2}{*}{ Rok } & \multirow{2}{*}{$\begin{array}{c}\text { Ogółem liczba osób } \\
\text { bezrobotnych }\end{array}$} & \multicolumn{2}{|c|}{$\begin{array}{c}\text { Osoby z wyższym wykształceniem } \\
\text { pozostające bez pracy }\end{array}$} \\
\cline { 3 - 4 } & & liczba & odsetek (\%) \\
\hline 2010 & 1954,7 & 204,7 & 10,5 \\
\hline 2015 & 1563,3 & 200,2 & 12,8 \\
\hline 2018 & 968,9 & 136,9 & 14,1 \\
\hline
\end{tabular}

Źródło: opracowanie własne na podstawie: Szkwarek (2019) 
W toku edukacji ważna jest znajomość czynników wpływających na indywidualną przedsiębiorczość. Istotne znaczenie mają tu cechy osobowościowe, wiek, płeć, system wartości, uwarunkowania otoczenia i aktywna polityka państwa (Maciejewski, 2018: 211; Kraśnicka, 2002: 51-59). Nadrzędną rolę w przejawianiu postawy przedsiębiorczej przypisuje się jednak wartościom. E. Gruszewska wskazuje, że inicjowanie działalności gospodarczej uwarunkowane jest takimi wartościami, jak skłonność do działania i podejmowania ryzyka, wytrwałość w realizacji celów, elastyczność, kreatywność i oryginalność (Gruszewska, 2014: 95, 100). Ważną rolę odgrywają również poczucie i dążenie do niezależności. W literaturze rozpowszechniony jest profil przedsiębiorczych cech, zaproponowany przez D.F. Kuratko i R.M. Hodgetts (Kuratko, Hodgetts, 2001: 99-104). Obejmuje on takie cechy, jak: zaangażowanie, determinacja, wytrwałość, potrzeba osiągnięć, inicjatywa, zorientowanie na okazje, odpowiedzialność, wewnętrzne umiejscowienie kontroli, podejmowanie skalkulowanego ryzyka, tolerancja niepewności, uczciwość i wiarygodność, umiejętność przyjmowania porażki, kreatywność i innowacyjność.

W aspekcie praktycznym, z punktu widzenia potrzeb polityki gospodarczej dla wspierania i rozwoju przedsiębiorczości, badanie postaw przedsiębiorczych na świecie prowadzone jest w ramach Global Entrepreneurship Monitor (Globalny Monitor Przedsiębiorczości). W ocenie postaw przedsiębiorczych uwzględnia się w nim następujące kryteria (jako procent populacji):

- dostrzeganie możliwości biznesowych - świadomość istnienia okazji dla rozpoczęcia działalności gospodarczej,

- samoocena zdolności przedsiębiorczych - posiadanie odpowiednich zasobów, umiejętności i wiedzy do rozpoczęcia działalności gospodarczej,

- obawa przed porażką - brak decyzji o wykorzystaniu dostrzeganej szansy z uwagi na obawy przed niepowodzeniem,

- intencje przedsiębiorcze - deklaracja uruchomienia działalności gospodarczej w ciągu najbliższych trzech lat (GEM Polska, 2017; GEM Polska, 2018).

Wyniki oceny postaw przedsiębiorczych Polaków zaprezentowano w tabeli 2. Cechą charakterystyczną jest wysoka ocena szans w otoczeniu na prowadzenie biznesu oraz bardzo niski odsetek osób deklarujących chęć założenia działalności gospodarczej w ciągu trzech lat. Mimo że ponad połowa badanych pozytywnie ocenia swój potencjał przedsiębiorczości, to dla ponad 1/3 respondentów strach przed porażką skutecznie może odwodzić od podejmowania tego typu aktywności.

Tabela 2. Ocena postaw przedsiębiorczych - wyniki dla Polski (dane za 2017 r.)

\begin{tabular}{|l|c|}
\hline \multicolumn{1}{|c|}{ Wskaźnik } & Wartość w \% \\
\hline Dostrzeganie możliwości biznesowych & 69,0 \\
\hline Samoocena zdolności przedsiębiorczych & 52,0 \\
\hline Obawa przed porażką & 34,0 \\
\hline Intencje przedsiębiorcze & 10,0 \\
\hline
\end{tabular}

Źródło: opracowanie własne na podstawie: GEM Polska (2018: 9)

Analiza wartości wskaźników przedstawionych w tabeli 2 wskazuje, że przed edukacją stoją wyzwania w zakresie niwelowania rozpiętości pomiędzy dostrzeganiem możliwości biznesowych i oceną zdolności przedsiębiorczych a dążeniem do wyboru własnej działalności jako opcji kariery zawodowej. 
Postawy przedsiębiorcze studentów - wyniki badań empirycznych

W strukturze badanych studentów (104 osoby) przeważały kobiety (69), które stanowiły $66,3 \%$ ogółu respondentów. Większość osób - 47,1\% - była mieszkańcami wsi, pozostały odsetek obejmował studentów wywodzących się z miast liczących do 20 tys. mieszkańców - 7,7\%, 20-100 tys. mieszkańców - 13,5\% oraz powyżej 100 tys. - 31,7\%. Większość próby stanowiły osoby do 22 roku życia (56,7\%), następnie osoby w wieku 23-24 lata $34,6 \%$ oraz powyżej 24 lat $-8,7 \%$. Kierunki techniczne studiowało $46,2 \%$ ankietowanych (48 osób), ekonomiczne - 27,9\% (29 osób), humanistyczne - 25,9\% (27 osób). Znaczący odsetek badanych - 46,1\% - wskazał, że ktoś w jego rodzinie lub wśród znajomych prowadzi działalność gospodarczą.

Powszechnie się uznaje, że osobę przedsiębiorczą, w odróżnieniu do osoby biernej, cechuje aktywność, działanie. Na ponadprzeciętną aktywność, określaną mianem proaktywności, zwraca uwagę S.R. Covey, który wskazuje, że stanowi ona zasadniczy klucz sukcesu (Covey, 2007). Z kolei odwołując się do stanowiska P.F. Druckera, można skonstatować, że przedsiębiorczość opiera się na ciągłym i niekończącym się procesie uczenia się poprzez działanie (Drucker, 1992). Badania studentów w tym względzie wskazują, że 40,4\% (42 osoby) podejmowały aktywność w zakresie podnoszenia swoich kompetencji przez udział w dodatkowych szkoleniach, w tym 40,5\% z kierunków technicznych (17 osób), 35,7\% z kierunków humanistycznych (15 osób) oraz 23,8\% z kierunków ekonomicznych (10 osób). Studenci angażowali się także w pracę zarobkową w czasie studiów - ponad połowa ankietowanych - 52,9\% - już pracowała, w tym głównie byli to studenci kierunków technicznych - 41,8\% (23 osoby) oraz humanistycznych - 34,5\% (19 osób), w dalszej kolejności ekonomicznych - 23,6\% (13 osób). Własną działalność gospodarczą prowadziło 7,7\% ankietowanych (6 mężczyzn i 2 kobiety), w tym z kierunków technicznych 5 osób, 2 osoby kierunków humanistycznych oraz 1 - z kierunku ekonomicznego.

Oceniając intencje przedsiębiorcze wskazano, że 58,7\% osób (61 osób z ogółu badanych) planowało wybrać prowadzenie własnej działalności gospodarczej jako ścieżkę kariery zawodowej. Interesujące, że w większym stopniu takie plany formułowały kobiety (37 kobiet - 60,7\%; 24 mężczyzn - 39,3\%). Jednak analiza wyników w obrębie grupy kobiet i mężczyzn rozważających możliwość założenia własnej firmy w odniesieniu do ogółu ankietowanych w tej grupie wskazuje, że to wśród mężczyzna był większy odsetek osób zainteresowanych tą formą aktywności zawodowej (68,6\%, tabela 3). Analiza kolejnych zmiennych - wieku, miejsca zamieszkania, tradycji prowadzenia działalności gospodarczej w rodzinie oraz studiowanych kierunków wykazała, że intencje przedsiębiorcze wzrastają wraz z wiekiem (pośrednio wynika to $\mathrm{z}$ dłuższego okresu edukacji, doświadczenia zdobytego podczas praktyk), ma na nie wpływ miejsce zamieszkania - większe plany z własną działalnością wiążą osoby wywodzące się ze środowisk wiejskich (być może wynika to ze studiowania w dużym mieście) oraz osoby z miast liczących powyżej 100 tys. mieszkańców. Posiadanie w rodzinie osób prowadzących działalność gospodarczą wpływało pozytywnie na chęć założenia własnej firmy. Wśród osób planujących działalność gospodarczą według kierunków studiowania najwięcej było humanistów, a nie - ekonomistów (tabela 3).

Myślenie o przyszłości dotyczyć powinno zagadnień i działań w sferach, na które mamy realny wpływ. Wpływ ten wyraża się przez podmiotowość oznaczającą poczucie sprawstwa, wpływu na swoje decyzje, która jest związana $\mathrm{z}$ wewnętrznym umiejscowieniem kontroli zdarzeń. Ma to zasadnicze zadanie dla edukacji w procesie kształtowania przedsiębiorczej 
postawy. W odniesieniu do planowania przyszłości i wyboru ścieżki zawodowej zostały zbadane stanowiska wobec przekonania o swoim własnym wpływie na dokonywane wybory oraz wpływie czynników zewnętrznych - rynku pracy, otoczenia (wpływ znajomych, mody, naśladownictwa itp.). Wyniki badań są optymistyczne - wskazują, że osobisty wpływ na podejmowane decyzje jest większy od wpływu otoczenia, co szczególnie uwidoczniło się w postawach osób wyrażających chęć założenia własnej działalności gospodarczej (tabela 4).

Tabela 3. Wybrane cechy diagnostyczne a intencje przedsiębiorcze badanych studentów

\begin{tabular}{|c|c|c|c|c|}
\hline \multirow[b]{2}{*}{$\begin{array}{c}\text { Kategoria badanych } \\
\text { (grupy osób) }\end{array}$} & \multirow[b]{2}{*}{$\begin{array}{c}\text { Liczba osób } \\
\text { ogółem } \\
(\mathrm{N}=104)\end{array}$} & \multicolumn{3}{|c|}{$\begin{array}{c}\text { Osoby planujące założenie działalności } \\
\text { gospodarczej }(\mathrm{N}=61)\end{array}$} \\
\hline & & $\begin{array}{l}\text { liczba osób } \\
\text { w grupie }\end{array}$ & $\begin{array}{c}\text { odsetek osób } \\
\text { w stosunku } \\
\text { do ogółu } \\
(\mathrm{N}=104) \\
\text { badanych \% }\end{array}$ & $\begin{array}{c}\text { odsetek osób } \\
\text { w stosunku } \\
\text { do liczby } \\
\text { w grupie \% }\end{array}$ \\
\hline Kobiety & 69 & 37 & 35,6 & 53,6 \\
\hline Mężczyźni & 35 & 24 & 23,1 & 68,6 \\
\hline Wiek do 22 lat & 59 & 32 & 52,5 & 54,2 \\
\hline Wiek 23-24 lata & 37 & 22 & 36,1 & 59,5 \\
\hline Wiek 25 i > & 8 & 7 & 11,5 & 87,5 \\
\hline Miejsce zamieszkania - wieś & 49 & 26 & 42,6 & 53,1 \\
\hline $\begin{array}{l}\text { Miejsce zamieszkania - miasto } \\
\text { do } 20 \text { tys. mieszk. }\end{array}$ & 8 & 6 & 9,8 & 75,0 \\
\hline $\begin{array}{l}\text { Miejsce zamieszkania - miasto } \\
20-100 \text { tys. mieszk. }\end{array}$ & 14 & 8 & 13,1 & 57,1 \\
\hline $\begin{array}{l}\text { Miejsce zamieszkania - miasto } \\
>100 \text { tys. mieszk. }\end{array}$ & 33 & 21 & 34,4 & 63,6 \\
\hline \begin{tabular}{|l|} 
Tradycje w rodzinie i otoczeniu \\
w prowadzeniu działalności
\end{tabular} & 24 & 24 & 39,3 & 100,0 \\
\hline Kierunki ekonomiczne & 29 & 17 & 27,9 & 58,6 \\
\hline Kierunki humanistyczne & 27 & 18 & 29,5 & 66,7 \\
\hline Kierunki techniczne & 48 & 26 & 42,6 & 54,2 \\
\hline
\end{tabular}

Źródło: opracowanie własne na podstawie badań ankietowych

Tabela 4. Ocena podmiotowości badanych studentów ogółem oraz według intencji przedsiębiorczych - średnia ważona

\begin{tabular}{|c|c|c|c|c|c|c|c|c|}
\hline \multirow[b]{2}{*}{ Stanowisko } & \multicolumn{3}{|c|}{ Waga } & \multirow{2}{*}{$\begin{array}{l}\text { Średnia ważona } \\
\text { dla ogółu } \\
\text { badanych }\end{array}$} & \multicolumn{3}{|c|}{ Waga } & \multirow{2}{*}{$\begin{array}{c}\text { Średnia ważona } \\
\text { dla planujących } \\
\text { działalność }\end{array}$} \\
\hline & 1 & 2 & 3 & & 1 & 2 & 3 & \\
\hline $\begin{array}{l}\text { Mam zasadniczy } \\
\text { wpływ na moją karierę } \\
\text { zawodową }\end{array}$ & 10 & 60 & 34 & 2,23 & 6 & 32 & 23 & 2,28 \\
\hline $\begin{array}{l}\text { Na moją karierę wpływa } \\
\text { sytuacja na rynku pracy } \\
\text { i otoczenie, w którym } \\
\text { żyję }\end{array}$ & 11 & 70 & 23 & 2,1 & 8 & 40 & 13 & 1,87 \\
\hline
\end{tabular}

Źródło: opracowanie własne na podstawie badań ankietowych 
Podobne badania realizowane są w ramach Globalnego Monitora Przedsiębiorczości, a dokonuje się w nich oceny motywów podejmowania działalności w rozróżnieniu na dwie kategorie, które mogą być związane z:

- przedsiębiorczością opartą na szansie - gdy przyszły przedsiębiorca dostrzega szansę biznesową i chce ją wykorzystać. Głównym motywem jest niezależność, chęć realizacji własnych celów;

- przedsiębiorczością z konieczności - gdy uruchomienie własnej działalności wiąże się z obawami, iż osoba nie znajdzie atrakcyjnej pracy lub pozostanie bezrobotna. Głównym motywem jest osiągnięcie lub wzrost dochodów.

W odniesieniu do Polaków, struktura motywacji do zakładania firm w 2017 r. była niezwykle korzystna - prawie $68 \%$ młodych firm stanowiły podmioty utworzone z powodu chęci wykorzystania szansy, zaś jedynie $9 \%$ to firmy założone z konieczności. Oznacza to, że na jedną firmę założoną z przymusu przypadało prawie osiem (dokładnie 7,5 ), które powstały z powodu chęci wykorzystania szansy, jaką daje własna działalność (GEM Polska, 2018: 33). Jednak w 2018 r. odsetek osób prowadzących młode firmy, które są motywowane pozytywnie, zmniejszył się w stosunku do 2017 r. z niemal 68\% do 55\%, natomiast odsetek osób motywowanych negatywnie odnotował nieznaczny spadek wartości (z 9\% do 8,4\%) (GEM Polska, 2019: 38).

Motywację do podejmowania własnej działalności można powiązać z oceną wyznawanych wartości. Przyjęto, że wartości predestynujące do zachowań przedsiębiorczych to: niezależność, realizacja własnych marzeń i celów oraz osiągnięcie satysfakcjonujących korzyści finansowych. Stabilizacja i unormowany czas pracy charakteryzują w większym stopniu pracę na etacie. Wyniki badań dowodzą spójności intencji przedsiębiorczych z wyborem ww. wartości - niższy odsetek badanych studentów deklarujących chęć założenia własnej działalności w stosunku do ogółu odpowiedzi wskazał na takie wartości, jak stabilizacja zatrudnienia oraz unormowany czas pracy. Studenci bardziej cenili niezależność, możliwość realizacji własnych celów oraz chęć osiągnięcia dużych korzyści finansowych. Ocena ww. wartości przez kobiety i mężczyzn, że większe predyspozycje do bycia przedsiębiorcą mają mężczyźni (tabela 5).

Potencjał dla przedsiębiorczości jest także kształtowany przez cechy osobowościowe oraz umiejętności. W toku badań stwierdzono, że najczęściej wskazywaną cechą wyróżniającą przedsiębiorczość w opinii badanych była kreatywność. Wymieniło ją 75\% ogółu badanych i w takim samym prawie stopniu wskazały na nią osoby planujące własną działalność. Cecha ta była też najistotniejsza dla studentów kierunków humanistycznych $(81,5 \%)$. Dla tej grupy studentów ważne były również odwaga i umiejętność podejmowania ryzyka (77,8\%). Z kolei rolę uporu i determinacji w działaniu podkreślili przede wszystkim studenci studiów technicznych $(77,1 \%)$ oraz osoby z grupy wyodrębnionej ze względu na deklarowane intencje przedsiębiorcze $(73,8 \%)$. To, co wyróżnia tę ostatnią wymienioną grupę studentów, to wskazanie przez blisko $2 / 3$ badanych $(62,3 \%)$ na znaczenie zdolności strategicznego myślenia i umiejętności wizualizacji zamierzeń (tabela 6 , rycina 1$)$.

Wyniki badań identyfikujących znaczenie cech i zachowań przedsiębiorczych wskazują na niższe oceny dla kluczowej, z punktu widzenia ich istoty, cechy, mianowicie proaktywności i podejmowania inicjatywy. Szczególnie studenci kierunków humanistycznych nie dostrzegali tych uwarunkowań. Z punktu widzenia istoty zachowań przedsiębiorczych ważna jest także potrzeba osiągnięć, wiara w siebie i własne możliwości, a także 
elastyczność w działaniu wobec dynamicznie zmieniających się warunków - wyniki badań wskazują, że w największym stopniu wyzwania te rozumieli studenci kierunków ekonomicznych.

Tabela 5. Wartości cenione przez badanych studentów ogółem, według płci oraz według planujących podjęcie działalności gospodarczej (\%)

\begin{tabular}{|l|c|c|c|c|}
\hline \multicolumn{1}{|c|}{ Wartości } & $\begin{array}{c}\text { Ogólem } \\
\mathbf{N = 1 0 4}\end{array}$ & $\begin{array}{c}\text { Kobiety } \\
\mathbf{N = 6 9}\end{array}$ & $\begin{array}{c}\text { Mężczyźni } \\
\mathbf{N}=\mathbf{3 5}\end{array}$ & $\begin{array}{c}\text { Planujący } \\
\text { podjęcie } \\
\text { działalności } \\
\mathbf{N}=\mathbf{6 1}\end{array}$ \\
\hline $\begin{array}{l}\text { Stabilizacja (pewność } \\
\text { zatrudnienia) }\end{array}$ & 59,6 & 62,3 & 54,3 & 55,7 \\
\hline Niezależność & 42,3 & 42,0 & 42,8 & 44,3 \\
\hline $\begin{array}{l}\text { Możliwość realizacji } \\
\text { własnych celów }\end{array}$ & 43,3 & 40,6 & 42,8 & 47,5 \\
\hline Unormowany czas pracy & 9,6 & 10,1 & 8,6 & 6,6 \\
\hline Korzyści finansowe & 33,6 & 27,5 & 40,0 & 39,3 \\
\hline
\end{tabular}

Źródło: opracowanie własne na podstawie badań ankietowych

Tabela 6. Cechy wyróżniające postawę przedsiębiorczą w opinii badanych studentów ogółem, wg kierunku studiowania oraz wg planujących podjęcie działalności gospodarczej (\%)

\begin{tabular}{|c|c|c|c|c|c|}
\hline \multirow[b]{2}{*}{ Cechy $^{*}$} & \multirow[b]{2}{*}{$\begin{array}{l}\text { Ogółem } \\
N=104\end{array}$} & \multicolumn{3}{|c|}{ Kierunek studiów } & \multirow{2}{*}{$\begin{array}{c}\text { Planujący } \\
\text { podjęcie } \\
\text { działalności } \\
\mathrm{N}=61\end{array}$} \\
\hline & & $\begin{array}{l}\text { ekonomiczny } \\
\qquad N=29\end{array}$ & $\begin{array}{c}\text { humanistyczny } \\
\mathrm{N}=27\end{array}$ & $\begin{array}{l}\text { techniczny } \\
\mathrm{N}=48\end{array}$ & \\
\hline Kreatywność & 75,0 & 65,5 & 81,5 & 77,1 & 75,4 \\
\hline $\begin{array}{l}\text { Proaktywność, } \\
\text { inicjatywa działań }\end{array}$ & 19,2 & 17,2 & 7,4 & 27,1 & 21,3 \\
\hline Potrzeba osiągnięć & 11,5 & 10,3 & 14,8 & 10,4 & 11,5 \\
\hline Upór, determinacja & 70,2 & 62,1 & 66,7 & 77,1 & 73,8 \\
\hline $\begin{array}{l}\text { Zdolności } \\
\text { przywódcze }\end{array}$ & 17,3 & 10,3 & 11,1 & 25,0 & 14,8 \\
\hline $\begin{array}{l}\text { Myślenie strategiczne, } \\
\text { wizja }\end{array}$ & 46,2 & 48,3 & 51,9 & 41,7 & 62,3 \\
\hline $\begin{array}{l}\text { Odwaga, } \\
\text { podejmowanie ryzyka }\end{array}$ & 62,5 & 62,1 & 77,8 & 54,2 & 65,6 \\
\hline $\begin{array}{l}\text { Wiara we własne } \\
\text { możliwości }\end{array}$ & 25,0 & 20,7 & 29,6 & 25,0 & 21,3 \\
\hline $\begin{array}{l}\text { Pracowitość, } \\
\text { umiejętności } \\
\text { organizacyjne }\end{array}$ & 45,2 & 51,7 & 40,7 & 43,8 & 46,0 \\
\hline Elastyczność & 3,8 & 6,9 & 3,7 & 2,1 & 4,9 \\
\hline
\end{tabular}

* Istniała możliwość wskazania kilku najważniejszych cech

Źródło: opracowanie własne na podstawie badań ankietowych 
Rycina 1. Cechy wyróżniające postawę przedsiębiorczą w opinii badanych studentów ogółem oraz według kierunku studiowania (\%)

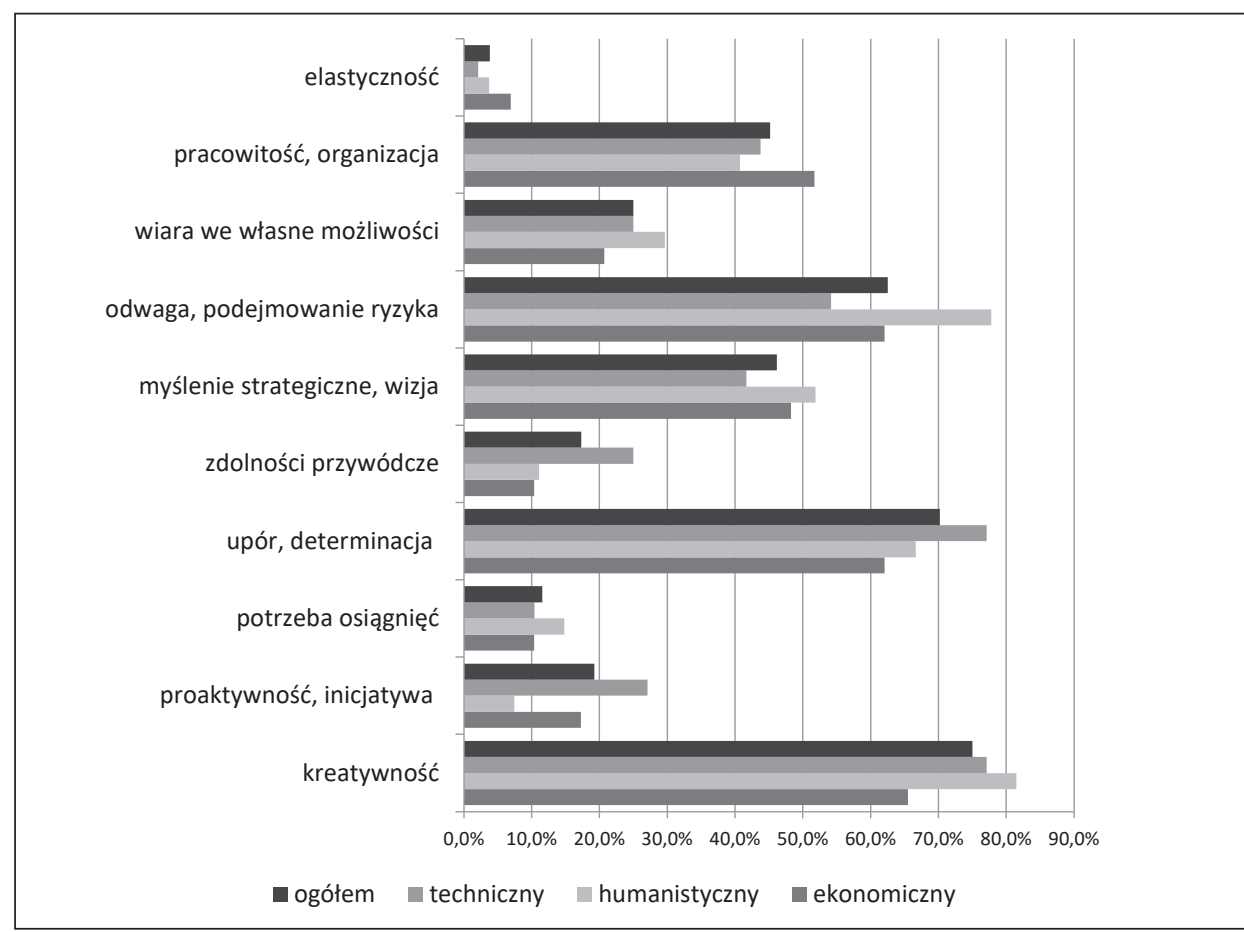

* Istniała możliwość wskazania kilku najważniejszych cech

Źródło: opracowanie własne na podstawie danych z tabeli 6

Studenci zostali także poproszeni o ocenę swoich cech i zachowań przedsiębiorczych. Wyniki zestawiono dla osób deklarujących chęć założenia własnej działalności gospodarczej oraz niemających takich planów (tabela 7).

Tabela 7. Opinie studentów na temat własnych cech osobowych i umiejętności uznawanych za determinanty zachowań przedsiębiorczych wg planujących i nieplanujących prowadzenie własnej działalności gospodarczej w przyszłości (\%)

\begin{tabular}{|l|c|c|}
\hline \multicolumn{1}{|c|}{$\begin{array}{c}\text { Pytania dotyczące wybranych cech } \\
\text { i zachowań respondentów }\end{array}$} & $\begin{array}{c}\text { Planujący } \\
\text { działalność } \\
\text { gospodarczą } \\
\mathbf{N}=\mathbf{6 1}\end{array}$ & $\begin{array}{c}\text { Nieplanujący } \\
\text { działalności } \\
\text { gospodarczej } \\
\mathbf{N}=\mathbf{4 3}\end{array}$ \\
\hline Czy jesteś osobą, która chętnie podejmuje inicjatywę? & & \\
tak & 82,0 & 58,1 \\
nie & 18,0 & 41,9 \\
\hline W jakim stopniu uważasz się za osobę kreatywną? & & \\
wysokim & 41,0 & 33,3 \\
średnim & 59,0 & 65,1 \\
niskim & - & 11,6 \\
\hline
\end{tabular}




\begin{tabular}{|c|c|c|}
\hline $\begin{array}{l}\text { W jakim stopniu oceniasz wiarę we własne } \\
\text { możliwości? } \\
\text { wysokim } \\
\text { średnim } \\
\text { niskim }\end{array}$ & $\begin{array}{r}39,3 \\
50,8 \\
9,9\end{array}$ & $\begin{array}{l}32,6 \\
48,8 \\
18,6\end{array}$ \\
\hline $\begin{array}{l}\text { Czy wykazujesz zdolności przywódcze? } \\
\text { tak } \\
\text { nie }\end{array}$ & $\begin{array}{l}68,9 \\
31,1\end{array}$ & $\begin{array}{l}46,5 \\
53,5\end{array}$ \\
\hline $\begin{array}{l}\text { Czy jesteś skłonny podejmować ryzyko, które wiąże } \\
\text { się z pozyskaniem lub utratą pieniędzy? } \\
\text { tak } \\
\text { raczej tak } \\
\text { nie } \\
\text { raczej nie }\end{array}$ & $\begin{array}{r}16,4 \\
37,7 \\
4,9 \\
41,0\end{array}$ & $\begin{array}{r}14,0 \\
14,0 \\
9,3 \\
62,8 \\
\end{array}$ \\
\hline $\begin{array}{l}\text { Czy wykazujesz konsekwencję w działaniu? } \\
\text { tak } \\
\text { raczej tak } \\
\text { nie } \\
\text { raczej nie }\end{array}$ & $\begin{array}{r}32,8 \\
55,8 \\
1,6 \\
9,8\end{array}$ & $\begin{array}{r}34,9 \\
46,5 \\
4,7 \\
13,9\end{array}$ \\
\hline $\begin{array}{l}\text { W jakim stopniu jesteś odporny na stres? } \\
\text { wysokim } \\
\text { średnim } \\
\text { niskim }\end{array}$ & $\begin{array}{l}24,6 \\
57,4 \\
18,0 \\
\end{array}$ & $\begin{array}{l}16,3 \\
60,5 \\
23,2 \\
\end{array}$ \\
\hline $\begin{array}{l}\text { W jakim stopniu oceniasz swoją motywację } \\
\text { w podejmowanych wyzwaniach? } \\
\text { wysokim } \\
\text { średnim } \\
\text { niskim }\end{array}$ & $\begin{array}{r}36,1 \\
57,4 \\
6,5\end{array}$ & $\begin{array}{r}27,9 \\
67,4 \\
4,7\end{array}$ \\
\hline $\begin{array}{l}\text { W jakim stopniu radzisz sobie } \mathrm{z} \text { rozwiązywaniem } \\
\text { problemów? } \\
\text { wysokim } \\
\text { średnim } \\
\text { niskim }\end{array}$ & $\begin{array}{r}42,6 \\
55,7 \\
1,7\end{array}$ & $\begin{array}{r}32,6 \\
58,1 \\
9,3\end{array}$ \\
\hline $\begin{array}{l}\text { W jakim stopniu oceniasz swoje umiejętności } \\
\text { myślenia strategicznego? } \\
\text { wysokim } \\
\text { średnim } \\
\text { niskim }\end{array}$ & $\begin{array}{r}42,6 \\
55,7 \\
1,7 \\
\end{array}$ & $\begin{array}{r}37,2 \\
53,5 \\
9,3\end{array}$ \\
\hline
\end{tabular}

Źródło: opracowanie własne na podstawie badań ankietowych

Wyniki badań dotyczące samooceny studentów w zakresie potencjału przedsiębiorczości wskazują na wyższe wartości deklarowanych cech i umiejętności studentów planujących zakładania działalności gospodarczej w przyszłości. Szczególnie duże różnice wystąpiły przy odpowiedzi na pytanie, czy osoba chętnie podejmuje inicjatywę w działaniu (tabela 7). W konfrontacji oceny wybranych własnych cech z cechami najbardziej 
pożądanymi w przedsiębiorczości zaskakuje relatywnie niska samoocena kreatywności. Należy jednak zauważyć, że opinie studentów z grupy niewykazujących intencji przedsiębiorczych względem własnych cech i umiejętności przydatnych w zachowaniach przedsiębiorczych nie odbiegają szczególnie „mocno” od ocen wskazywanych przez ankietowanych z pierwszej grupy. Pozwala to oczekiwać, że w perspektywie kształtowania przedsiębiorczego społeczeństwa badani studenci także w pracy najemnej będą wykazywać pożądane z punktu widzenia wyzwań współczesnej gospodarki zachowania.

\section{Zakończenie}

Kształtowanie postaw przedsiębiorczych młodego pokolenia współcześnie należy traktować jako niezbędny czynnik warunkujący rozwój, w myśl P. Druckera społeczeństwa przedsiębiorczego, potrafiącego funkcjonować w warunkach gospodarki opartej na wiedzy oraz skutecznie budować konkurencyjność gospodarki. W ocenie korzyści na poziomie indywidualnym, przedsiębiorcza postawa współcześnie, wobec zmiennego rynku pracy, stanowić może o pożądanej i alternatywnej opcji kariery zawodowej. Jednak kształcenie w zakresie przedsiębiorczości stanowi określone wyzwania dla edukacji. Powinno być ukierunkowane na zrozumienie przede wszystkim istoty przedsiębiorczości - kształtowanie poczucia podmiotowości, kreatywności, odwagi i przede wszystkim wiary we własne możliwości stanowi bowiem pierwotną przesłankę zachowań przedsiębiorczych. Dowodzą tego zaprezentowane wyniki badań wskazujące, że większe przekonanie o własnym potencjale przedsiębiorczości implikuje większą skłonność do podjęcia działalności gospodarczej w przyszłości. Poznanie postaw młodego pokolenia w kontekście różnic regionalnych w rozwoju społeczno-gospodarczym uzasadnia potrzebę badań cech, predyspozycji przedsiębiorczych, uznawanych wartości w przekrojach regionalnych. Wyniki badań mają charakter sondażowy, niemniej pozwalają stwierdzić, że w warunkach środowiska społeczno-gospodarczego województwa podkarpackiego przedsiębiorczość wśród badanych studentów jest w dużej mierze aprobowaną postawą, a rozpoczęcie działalności gospodarczej - ewentualną opcją kariery zawodowej. Zidentyfikowane deficyty w zakresie wybranych cech i kompetencji przedsiębiorczych powinny stanowić inspirację do doskonalenia oferty edukacyjnej uczelni wyższych w tym zakresie.

\section{Literatura}

References

Covey, R.S. (2007). 7 nawyków skutecznego działania. Warszawa: Dom Wydawniczy Rebis.

Dominiak, P. (2005). Sektor MSP we współczesnej gospodarce. Warszawa: PWN.

Drucker, P.F. (1992). Innowacja i przedsiębiorczość. Praktyka i zasady. Warszawa: PWE.

Foster, R., Kaplan, S. (2003). Twórcza destrukcja. Łódź: Galaktyka.

GEM Polska. (2017). Raport z badania Global Entrepreneurship Monitor - Polska. Warszawa: PARP. Pozyskano z: https://www.parp.gov.pl/storage/publications/pdf/parp_2_raport_gem_internetpl_2017.pdf

GEM Polska. (2018). Raport z badania Global Entrepreneurship Monitor - Polska 2017/18. Warszawa: PARP. Pozyskano z: https://www.parp.gov.pl/storage/publications/pdf/raport\%20z\%20badania\%20global\%20entrepreneurship\%20monitor_2017_2018.pdf

GEM Polska. (2019). Raport z badania Global Entrepreneurship Monitor - Polska. Warszawa: PARP. Pozyskano z: https://www.parp.gov.pl/component/publications/publication/gem-polska-raport-z-badania-przedsiebiorczosci-2019 
Gruszewska, E. (2014). Transformacja wartości a postawy przedsiębiorcze Polaków. Annales. Etyka w Życiu Gospodarczym, 17(3), 91-101.

Kaliszczak, L. (2011). Schumpeterowska teoria przedsiębiorczości i jej współczesne implikacje. Nauki o zarządzaniu. Management Science. Prace Naukowe Uniwersytetu Ekonomicznego we Wrocławiu, 216(8), 345-355.

Kaliszczak, L., Sieradzka, K. (2018). Zachowania przedsiębiorcze - wspótczesne wyzwania. Radom: Wydawnictwo Spatium.

Kraśnicka, T. (2002). Koncepcja rozwoju przedsiębiorczości ekonomicznej i pozaekonomicznej. Seria: Prace Naukowe, Akademia Ekonomiczna w Katowicach. Katowice: Wydawnictwo Uczelniane AE.

Kraśnicka, T., Głód, G., Ludvik, L., Peterkova, J. (2014). Uwarunkowania intencji przedsiębiorczych studentów uczelni ekonomicznych Polski i Czech. Przedsiębiorczość - Edukacja [Entrepreneurship - Education], 10, 316-332.

Kuratko, D.F., Hodgetts, R.M. (2001). Entrepreneurship. A contemporary approach. Fort Worth: Harcourt College Publishers.

Maciejewski, M. (2018). Postawy i działania przedsiębiorcze w Polsce i na świecie w świetle oceny kształcenia biznesowego. Horyzonty Wychowania, 17(43), 209-220. doi: 10.17399/HW.2018.174318.

Rachwał, T., Wach, K. (2016). Badanie intencji przedsiębiorczych młodego pokolenia: wyniki ankietyzacji wśród studentów kierunków nieekonomicznych. Przedsiębiorczość - Edukacja [Entrepreneurship - Education], 12, 405-415.

Stevenson, H.H., Jarillo-Mossi, J.C. (1990). A Paradigm of Entrepreneurship: Entrepreneurial Management. Strategic Management Journal, 11(4), 17-27.

Szkwarek, W. (2019). Wykształceni bezrobotni. Pozyskano z: https://www.bankier.pl/wiadomosc/ Wyksztalceni-bezrobotni-7652956.html

Timmons, J.A. (1990). New venture creation. Boston: Richard D Irwin.

Wach, K., Wojciechowski, L. (2016). Entrepreneurial Intentions of Students in Poland in the View of Ajzen's Theory of Planned Behaviour. Entrepreneurial Business and Economics Review, 4(1), 83-94.

Wąsowska, A. (2016). Who Doesn't Want to be an Entrepreneur? The Role of Need for Closure in Forming Entrepreneurial Intentions of Polish Students. Entrepreneurial Business and Economics Review, 4(3), 27-39.

Wennekers, S., Thurik, R. (1999). Linking Entrepreneurship and Economic Growth. Small Business Economics, 13, 27-56.

Żur, A. (2014). Exploring the Role of Inspiration in Entrepreneurship Education. Horyzonty Wychowania, 13(26), 179-194.

Lidia Kaliszczak, dr nauk ekonomicznych, zastępca dyrektora Instytutu Ekonomii i Finansów w Kolegium Nauk Społecznych Uniwersytetu Rzeszowskiego. Jej zainteresowania badawcze dotyczą istoty, uwarunkowań i form przejawiania przedsiębiorczości, rozwoju małych i średnich przedsiębiorstw, kreatywności oraz innowacyjności.

Lidia Kaliszczak, $\mathrm{PhD}$ in Economics, deputy director of the Institute of Economics at the College of Social Sciences of the University of Rzeszow. Her research interests relate to the essence, conditions and forms of entrepreneurship, the development of small and medium enterprises, creativity and innovation.

ORCID: https://orcid.org/0000-0002-1879-1352

\author{
Adres/Address: \\ Uniwersytet Rzeszowski \\ Instytut Ekonomii i Finansów \\ ul. Ćwiklińnkiej 2 \\ 35-601 Rzeszów, Poland \\ e-mail: lidia.kaliszczak@gmail.com
}


Katarzyna Sieradzka, dr nauk ekonomicznych, wykładowca na Wydziale Ekonomii i Finansów Uniwersytetu Technologiczno-Humanistycznego w Radomiu. Jej zainteresowania badawcze i naukowe dotyczą determinant rozwoju sektora przedsiębiorstw, w tym źródeł finansowania, innowacyjności i konkurencyjności.

Katarzyna Sieradzka, PhD in Economics, lecturer at the Faculty of Economics and Finance of the University of Technology and Humanities in Radom. Her research and academic interests relate to the determinants of the enterprises' development, including sources of financing, innovation and competitiveness.

ORCID: https://orcid.org/0000-0002-2903-8219

\section{Adres/Address:}

Uniwersytet Technologiczno-Humanistyczny im. K. Pułaskiego w Radomiu

Wydział Ekonomii i Finansów

Katedra Ekonomii

ul. Chrobrego 31

26-600 Radom, Poland

e-mail: k.sieradzka@uthrad.pl 